\title{
Prospects and Issues Related to Tea Cultivation in Mid Country Homegarden Based Tea Smallholdings in a Selected Village in Sri Lanka
}

\author{
W.G.C. Wekumbura, A.J. Mohotti ${ }^{1 *}$, E. Frossard ${ }^{2}$, S.T. Kudagammana ${ }^{3}$, K.D.R.R. Silva ${ }^{4}$ \\ Postgraduate Institute of Agriculture \\ University of Peradeniya \\ Sri Lanka
}

\begin{abstract}
Smallholder tea sector plays a vital role in Sri Lanka's economy and also in the rural economy. Smallholder tea lands are associated with homegardens in many areas, which have implications towards the development and maintenance of the homegardens. Thus, this study was focused on identifying prospects and issues in tea production of smallholders who have a tea-based homegarden in Aluthgama village, Nawalapitiya. Data was collected through a questionnaire survey using 100 growers to include the cost item, family involvement, extension service interaction, new technologies and issues. Chi square test, correlation and descriptive statistics were used in data analysis. The relative severity index (RSI) was calculated to determine the relative importance of various issues of smallholders. The tea was grown adjoining the homegarden or as a mixed cropping system. Tea was preferred due to the higher income from tea lands. Major cost items were fertilizer and labour for plucking. In more than $70 \%$ of households, at least one family member got involved in weeding followed by plucking to reduce cost of production. Out of the 15 identified problems, RSI value showed that climate effect is the highest influencing issue followed by low productivity, labour shortage, high cost for labour and land suitability. On the contrary, land ownership, buyer shortages, long crop duration and time taken to receive money after sales were not considered as matters in the studied area.High cost of production in tea cultivation is a challenge. Therefore, to reduce the cost of production and to overcome labour and land problem, involvement of family members was significant. In order to overcome uncertain future of tea, promotion and development of tea-based homegarden can be a viable approach to secure the food and income among smallholder farmers.
\end{abstract}

Keywords: Homegarden, problems in tea cultivation, relative severity index, tea smallholders

\section{INTRODUCTION}

Tea is the cheapest beverage in the world next to water. It is obtained from the tea plant (Camellia sinensis L. (O.) Kuntze), which belongs to family Theaceae. Tea is a crop of wide adaptability to different climates and soils in various parts of the world. The tea produced in Sri Lanka is popularly known as "Ceylon tea" and has a high demand as 'high quality tea' in

\footnotetext{
Department of Crop Science, Faculty of Agriculture, University of Peradeniya, Peradeniya, Sir Lanka

Institute of Agricultural Sciences, ETH - Zurich, Switzerland

Department of Paediatrics, University of Peradeniya, Sri Lanka

4 Department of Applied Nutrition, Wayamba University of Sri Lanka, Sri Lanka

* Corresponding Author: mohottij@yahoo.com
} 
the international trade and continues to maintain its creditability in terms of quality and cleanliness of the product (Kottawa-Arachchi et al., 2013). As the leading plantation crop in Sri Lanka, it accounts for $2 \%$ of GDP, contributing to over US $\$ 1.5$ billion to the economy of Sri Lanka. It employs over 1 million people directly or indirectly and contributes to $15 \%$ of total export earnings and $58 \%$ of the total agricultural export earnings (Hilal and Mubarak, 2013; EDB, 2016).

Corporate sector (large plantations) and smallholder sector are the two main sectors of tea industry in Sri Lanka. Lands less than 10 acres (4 ha) in extent are considered as "tea smallholdings" according the Tea Control Act (Perera, 2014). Total land extent of tea smallholdings in Sri Lanka was 120,955 hectares in 2012, out of the total tea extent of 221,968 hectares. Smallholder sector dominate in the country with a production of $76 \%$ of the national tea output, and made tea productivity of $2125 \mathrm{~kg} \mathrm{ha}^{-1}$ year $^{-1}$. Further, it provided livelihood for an estimated 4 million, which is about $20 \%$ of the total population (TSHDA, 2010, 2011 and 2012).

In Sri Lanka, at present, smallholder tea cultivation is spread in fourteen districts in high, mid and low elevations. Plantation company-owned large tea estates are dominated in high and mid elevations. Tea smallholders are more concentrated in low elevations, in the districts of Rathnapura, Galle, Matara and Kaluthara (75\% of the extent) (Fernando, 2015).

Homegardens are farming systems that are located adjacent to homes, in close association with family activities and a wide diversity of plant species and livestock species to meet family needs (Landon-Lane, 2004). The structure and management of a homegarden varies from place to place, depending on ecological, socio-economic and cultural factors of the respective region. Homegarden has a functional relationship with its occupants related to economic, biophysical and social aspects (Weerakoon, 2011). Homegardens found in tropical areas are considered as 'multi-species, multi-storied cropping systems'. The selection of a crop to be planted in a homegarden is based on the characteristics of the plant and its value. Trees or shrubs grown in the homegarden could be classified into several groups based on their functional values (Fernandes and Nair, 1986; Kumar and Nair, 2004). A significant majority of homegardens in Sri Lanka are maintained to produce food (vegetables) for home use and secondly, the sale of the excess to derive an income (Sangakkara and Frossard, 2016).

Most intensive homegarden systems in Sri Lanka are found in the Kandy and Matale districts, which are known as 'Kandyan forest gardens' and are well known world over (Jacob and Alles, 1987; Pushpakumara et al., 2012). Tea planting in small land blocks has become increasingly popular among homegardeners in Sri Lanka due to various reasons. Tea cultivation is the main source of income for some homegardeners in the country in some areas (i.e. main income source of $50 \%$ of smallholders in whole country) (Cyril, 2009). Tea cultivation is practiced by many small scale farmers due to the incentives provided by the government. Continuous, year-round, steady flow of cash income also motivates farmers for tea cultivation. Tea is a crop which has a wide adaptability to different agro-climatic conditions, hence distributed throughout the wet and intermediate zone in all three elevations of Sri Lanka (Watson, 2008a). In addition, less price fluctuation, less incidence of pests and diseases and easy access to market and other facilities compared to other crops such as rubber and vegetables catch the attention of smallholder subsistence farmers where land is available around the dwellings which are utilized for unplanned homegarden system. 
The development and maintenance of a homegarden is a collective effort of family members (Nair, 1993). The land that belongs to smallholders are limited in the country especially in up and mid country wet zone (Pushpakumara et al., 2012). Therefore, leaving space for the homegarden, much of the rest of the land is cleared and cultivated with tea as a sole crop. Some farmers adopt tea cultivation in a separate land without disturbing homegarden structure. However, attention towards development and maintenance of homegarden becomes less when an adjoining tea land is present. As a source of cash income, priority in terms of use of family labour and intensive care is given to tea fields by farmers while neglecting the homegarden even though it supplements some food, material and income.

Many studies identify the value of homegardens and how they contribute to family nutritional status and their place in the farming systems of the rural landscape (Fernandest and Nair, 1986; Marsh, 1998; Landon-Lane, 2004; Kumar and Nair, 2007; Galhena et al., 2013). Despite the potential benefits of homegardens, a review of literature clearly showed that there is lack of research on contribution and influence of perennial cash crops i.e. tea, coffee, cocoa on the structure and function of homegardens in different locations.

\section{Objectives}

Within this context, this study aimed to identify prospects and issues related to homegarden based tea smallholdings that can have a direct influence on sustainable development of homegardens in the Aluthgama village, Nawalapitiya, Sri Lanka.

The specific objectives of the study were to identify the characteristics of homegarden based tea smallholder system with special reference to identifying the contribution of the farmers and the family members for the cultivation and maintenance of the homegardens and the tea lands, analyse the contribution of farmer towards reduction of cost of production, the, management practices followed by farmers and how tea extension service can be influenced in development of tea cultivation along with importance of new technologies.

\section{Selection of area}

\section{METHODOLOGY}

About $90 \%$ of farmers in Aluthgama village, Nawalapitiya region (WM1a) of Kandy district cultivate tea in lands adjoining their homegardens, some along with spice and beverage crops. Further, the tea smallholder farmers in the area (mid country) receive relatively lesser attention from the authorities than low elevation tea smallholders due to the lesser land extent in tea cultivation, although significant characteristic features exist in these homegardens, and they contribute to the family income. On this basis, the present study was carried out in Aluthgama village, Nawalapitiya.

Over 200 homegardens, all of which belonging to the owners within this village cultivate tea in their land as a cash crop for income. Out of the total of approximately 200 smallholder tea growers in the area, 100 growers (50\% of the population) were randomly selected for the study.

The study was conducted in December 2015.

\section{Data collection}


The study was based on data personally collected with the help of a pre-tested questionnaire. This questionnaire was prepared using available literature, discussions with some farmers in the area, and personnel experience of the researcher in eliciting the required data from the respondents. The study included data related to various aspects of tea cultivation which are related to the agronomic, marketing, extension services, technology adoption and cost items and homegardening.

\section{Demographic and cultivation data}

Personal details of cultivator and their family members including age, occupation and educational status were collected on the basis of the importance of tea cultivation and homegardening towards family income and involvement of family members in cultivation. Information regarding tea cultivation included owned land area and land area occupied by tea, cropping pattern followed, availability of homegarden, age of tea, pruning cycles, cost of production and price and major cost items to rank as 1 to 4 . Further, expansion and continuation of tea cultivation and their expectations regarding future tea cultivation were also gathered to assess the impact of tea on these farmers.

Details of homegardens were included as a measure of their involvement, purpose, uses and knowledge in homegardening. Cultivation and management practices, crop and output details, and contribution of family members towards tea cultivation and homegardening were also gathered. In addition, preferred crop and livestock species to incorporate to the homegardens were also collected.

\section{Prospects and issues in tea cultivation}

Problems faced with cultivation until marketing were gathered using fifteen questions. Effect of the problem were measured as a five point Likert scale i. e. very serious problem (1), serious problem (2), moderate problem (3), minor problem (4) and not a problem (5).

\section{Interaction of extension services}

Tea extension services, interaction of extension workers with farmers, the extension method they think have more importance and how to get more knowledge regarding tea cultivation were also included into questionnaire.

\section{New techniques and technologies}

Awareness and usefulness of new techniques and technologies in tea cultivation were gathered through the questionnaire. In addition, constraints in adopting new techniques and technologies in tea cultivation were measured using five point Likert scaled questions.

\section{Data analysis}

To analyse and measure problems and constraints faced by small tea growers and the relationship among different variables, used the statistical tools Chi square test, correlation and descriptive statistics. Data were analysed using SPSS (version 21) software and presented after calculation of percentage. 


\section{Estimation of severity of issue: Relative Severity Index (RSI)}

The relative severity index (RSI) (Iyer and Jha, 2005) was used to determine the relative importance of the various issues smallholder tea cultivator faced. The five-point scale ranging from 1 (very serious problem) to 5 (not a problem) was adopted, and transformed to RSI for each issue using following equation.

$R S I=\frac{\sum_{i=1}^{N} W i}{H^{*} N}$

$W i$ is the weightage given to each issue by the respondents which ranged from 1 to $5, H$ is the highest weightage equal to 5 , and $N$ is the total number of respondents.

\section{RESULTS AND DISCUSSION}

The land owners (males) were in the age range between 25 to 70 years of age while land owner's median age was 54.5 years, and all of them (100\%) got involved in tea cultivation. According to a recent study carried out by tea smallholder development authority (TSHDA), majority of smallholder farmers in Sri Lanka were in the age range between 26-55 years $(66.5 \%)$ and nearly $30 \%$ were more than 56 years old (Fernando, 2015). The results of the present study indicated poor attraction of younger generation towards tea cultivation in the study area showing $88 \%$ were more than 40 years old. Eighty three percent of families consisted of 3 to 5 family members, while another considerable number consisted of 4 to 5 members in the family. Farming was the main occupation of majority of members of the community $(28 \%)$. This was followed by employment in the government sector $(23 \%)$, and private sector $(13 \%)$.

Of the studied cultivated lands, $82 \%$ of lands were inherited from the parents, and another $17 \%$ of lands have been bought for the purpose of tea cultivation. A $36 \%$ of farmers used $50 \%$ of the total land area owned for tea cultivation, while another $33 \%$ of farmers used 50 $75 \%$ of available land extent for tea cultivation. Land extent belonging to farmers ranged between $0.2-0.8$ hectares $(0.5-2$ acres $)$. In a related study, the TSHDA found out that majority of the total tea land extent in Sri Lanka was in holdings less than 0.5 ha $(88.19 \%)$ and belong to a single ownership (64.9\%) (Cyril, 2009; TSHDA, 2012; Fernando, 2015).

Majority of farmers used at least $1 / 4$ of the land extent for other purposes, including construction of the house and managing land as a homegarden. However, $95 \%$ of farmers participated in the present study claimed that they do not have separate land as a homegarden, although the observation was that most of them used a part of their land as a homegarden. These contradictory results revealed that farmers pay less attention for their homegarden and they pay more attention to cash crops when compare to subsistence areas. About $93 \%$ farmers cultivated tea as a mixed cropping system in this area while in the whole country it is approximately $32 \%$ (Cyril, 2009).

Considering tea cultivation, the main cost items are shown in Table 1. The highest cost incurred was for the inputs (fertilizer and chemicals). Cost of production of $1 \mathrm{~kg}$ of green tea leaves was approximately Rs. $25.00-32.00$, while in literature it is reported to be more than Rs. 45.00 (Fernando, 2015). Lower cost of production amongst the smallholders in the studied area may be due to the use of family labour for different activities. In other tea 
growing areas of the country, high cost of production resulted due to the incorporation of labour for activities including plucking (Watson, 2008b).

Table 1. Ranking by farmers for cost of different management practices in the descending order

\begin{tabular}{lllll}
\hline \multirow{2}{*}{ Cost item } & \multicolumn{4}{l}{ Percentage of Farmers Voted for Each Ranking } \\
\cline { 2 - 5 } & $1 *$ & 2 & 3 & 4 \\
\hline $\begin{array}{l}\text { Inputs (fertilizer/chemicals) } \\
\text { Labour-plucking }\end{array}$ & $54 \%$ & $44 \%$ & $2 \%$ & \\
\cline { 2 - 5 } $\begin{array}{l}\text { Labour - pruning and planting } \\
\text { Labour - weeding and } \\
\text { management practices }\end{array}$ & $44 \%$ & $15 \%$ & $20 \%$ & $20 \%$ \\
\cline { 2 - 5 } & $2 \%$ & $31 \%$ & $48 \%$ & $19 \%$ \\
\cline { 2 - 6 } & & $10 \%$ & $29 \%$ & $61 \%$ \\
\hline
\end{tabular}

*Note: Rank 1 denotes the largest expenditure incurred for the specific practice by individual farmers

Results of the present study also indicated that $73 \%$ of the tea smallholders relied on at least one family member for the activities related to tea cultivation, while another $27 \%$ of them did not get involved in activities of their tea lands and labour was hired. All those who spent time in the tea lands, spent more than 4 hours/ day in the tea land, but only 1-2 hours/day in the homegarden for maintenance and work. Majority of the involvement of the family members were for weeding (88\%), followed by plucking $(64 \%)$ and fertilizer application (51\%). Also, $93 \%$ of farmers practiced hand weeding. All these results clearly stressed the importance of family member involvement towards tea cultivation and $100 \%$ farmers believed that it definitely reduces the cost of production.

Almost all homegardens in the current study had vegetables (100\%) as the main crop, followed by fruits $(66 \%)$, flowering plants $(41 \%)$, timber plants $(37 \%)$, leafy vegetables $(33 \%)$, and spices $(20 \%)$. Main purpose of homegardening in the area was for household consumption (100\%), followed by selling any excess to village shop (54\%) and to a collector (20\%). A 33\% practiced homegardening as an additional income source, a $25 \%$ as an occupation, and another $20 \%$ as a personal interest or a hobby. Most preferred crops in the area were tea, vegetables and flowering plants.

Twenty percent of households reared livestock species and $30 \%$ were willing to rare livestock. Amongst the livestock species, layer chicken dominated and was the most preferred.

The highest income for the farmers was obtained from tea, followed by homegarden products vegetables, livestock, spices and fruits. This emphasizes that these farmer's main attention was captured by tea cultivation.

\section{Problems and issues related to tea smallholders in the region Relative Severity Index (RSI)}

The issues were ranked based on the RSI values and rankings were assigned to each problem, and the severity of the problem was identified based on the RSI, which are presented in Figure 1. The higher the value of RSI, the problem was considered as less important or not a serious issue and vice versa. 


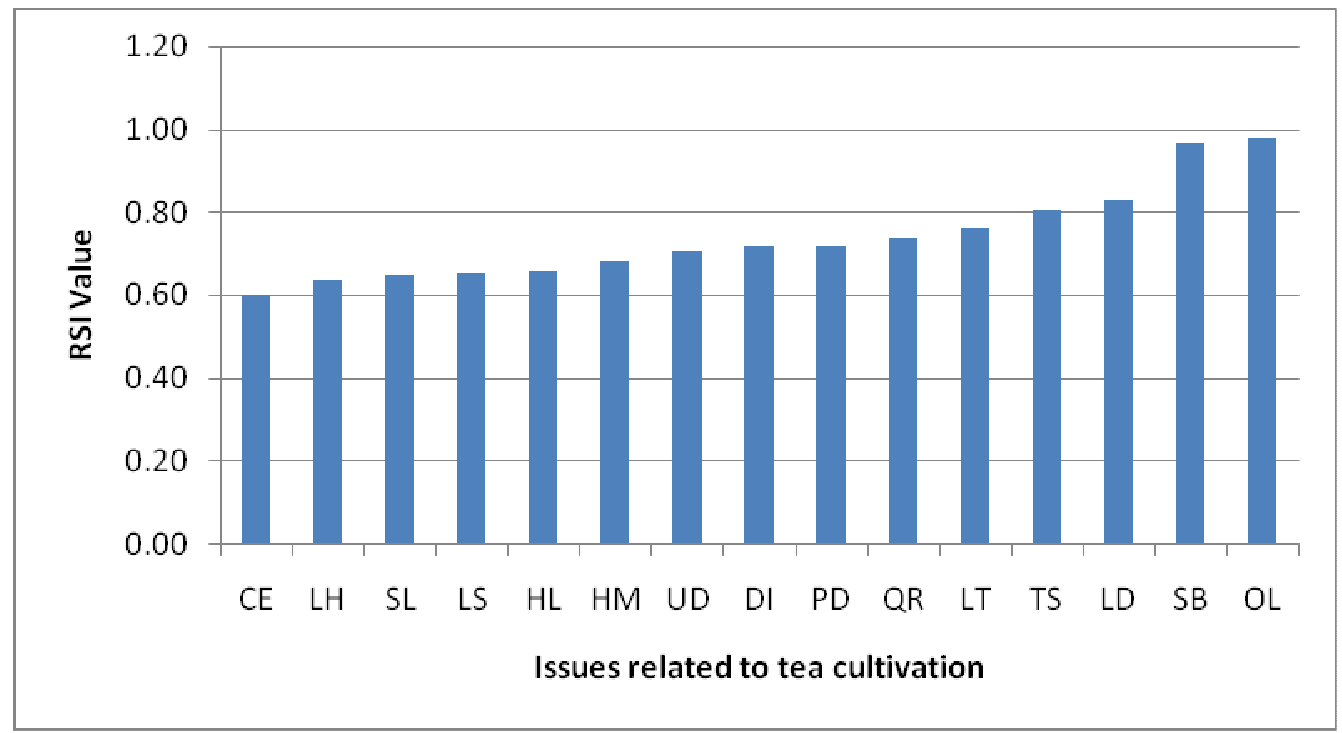

Fig 1. Relative Severity Index values related to issues of smallholder tea cultivators in Aluthgama, Nawalapitiya area. (Abbreviations: CE: Climatic effect, LH: low harvest, SL: shortage of labor, LS: land suitability, HL: high cost of labour, HM: management difficulties, UD: unnecessary deductions in weighing, DI: delay in payments of instalments, PD: pests and diseases, QR: quality requirement, LT: land preparation techniques, TS: time taken to receive money after selling, LD: long crop duration, SB: shortages of green tea buyers, OL: land ownership issues.)

Amongst the 15 problems identified by the farmers, climatic effect (unexpected rain/drought) was considered as a major problem by all the smallholders (100\%). The area belongs to the wet zone with a high total annual rainfall $(>2500 \mathrm{~mm})$ with a high expectancy, hence in general, not considered as an area prone to prolonged drought. Therefore, change in rainfall pattern and drought would not much affect plant growth and yield in the considered area compared to annual crops (Wijeratne et al., 2007). However, some unexpected, extremely high rainfall events were observed in the area (and in many parts of the country) recently (Darshika and Premalal, 2015), which could have had detrimental effects on many management practices such a plucking, which the farmers may have referred to.

According to the Chi square value $\left(\chi^{2}=9.47, \mathrm{P}=0.304\right)$ there was no relationship between the land size and quantity of harvest in the area. Compared to the estate sector in Sri Lanka, smallholder productivity is higher, which is about 2100 made tea $\mathrm{kg} / \mathrm{ha} / \mathrm{year}$ (Mohamed and Zoyza, 2006; Shyamalie, 2012). Yield varies widely amongst the smallholdings. Soil and climatic factors affect the harvest, but they are common for most farmers. Age of the plantation, type of cultivar, number of pruning cycles, number of days after pruning and number of days after fertilizer application are the common factors identified as most crucial factors that affect the current harvest/ level of harvest. Therefore, comparison of harvest among farmers is difficult as it is a combination of multiple factors (Watson, 2008b).

Labour is a critical issue faced by large and smallholder tea plantations of Sri Lanka in the present context. Interestingly, in the present study, only a $32 \%$ and $24 \%$ mentioned that it is a serious and moderate problem respectively for them. These results proved that many of the 
smallholder farmers get the involvement of their family members for tea cultivation. Further, $56 \%$ of tea smallholders mentioned that cost for labour is too high (Rs.600.00 -1000.00 per day). Due to scarcity of labour in the country, current daily wage rate in the agricultural sector for a female worker is more than Rs.600.00 and for a male worker more than Rs. 1000.00 for a duration of six to seven hours, and in construction fields it can be more than Rs. 1500.00. Therefore, the labour problem can be considered as becoming a serious issue in the agricultural sector and will continuously increment the cost of production of agricultural commodities in Sri Lanka compared to other countries (Warusamana, 2013).

Major problems associated with land suitability were the presence of large boulders, gravel layers, shallow soil and steepness. These farmers obtain a considerable yield with satisfactory plant growth and development, and bush cover since the selected area possesses the ideal geographical conditions for tea cultivation (WM1a agro ecological zone) (Watson, 2008a). Although green tea leaf buyers try to attract more farmers, $57 \%$ of smallholders observed dishonesty and unnecessary deductions in the weighing point. Majority of farmers mentioned that green leaf collectors use improper scales for weighing, do not use modern and certified scales and undue deductions for the weight of bag, and for water on rainy days. There are many green leaf buyers and supplying agents in the area as it is a profitable business at present. However, majority of them failed to gain farmer's trust.

Relatively long lag without a crop after planting was not identified by farmers as a problem in this study. It may be due to the fact that all the respondents in the study owned tea lands older than four years. The tea plant is ready for harvest after 3 years, and within 4-5 years it can produce a considerable harvest (Watson, 2008b).

Regarding the subsidy scheme conducted by the government for new cultivation, $54 \%$ of farmers stated that delay in payment of instalments during the new cultivation was a problem. Tea Planting subsidies were provided to cover $25 \%$ of the cost (TSHDA, 2012) and farmers expected to use this money to cover subsequent expenditure during planting.

When questioned on pests and diseases in tea, $97 \%$ of the farmers identified blister blight as the most common disease, and they could not identify any other disease. Blister blight is a disease that affects immature tea leaves, with a high occurrence during rainy, cloudy and misty conditions. The farmers identified above disease using their own experience. A $65 \%$ of farmers could identify the pest and disease through and 15\% farmers used knowledge gained through extension programs conducted by tea research institute (TRI) and TSHDA and another $15 \%$ of farmers used both experience and knowledge gained through the extension services to identify pest and disease incidences in their field. Land preparation and related technology was considered as a minor problem for majority of the farmers probably due to the small land size and majority of them had already established tea cultivations.

Time taken to receive money after selling and quality requirements of buyers were not considered as a serious problem indicating a stable market. The presence of many buyers/agents to collect tea leaves from the tea smallholders who provided them with timely payment which can be considered as important in maintaining the trust towards the green leaves buyer. Lower harvesting frequencies indicated selective harvesting of immature tea leaves with a good standard by family labour. According to the TSHDA, $56 \%$ of smallholders maintained seven day harvesting frequency, and another 26\% maintained 8-10 day harvesting interval. In the mid country 8-10 day interval is common, but this varies with the prevailing weather condition, other management practices, cultivar etc. (Watson, 2008b). In addition, the Sri Lanka Tea Board has imposed strict measures recently in maintaining 
good leaf standard with incentives for good leaves. However, in the study area, green leaf buying was handled by collectors and dealers of some private factories such as Greenwood, Galaboda, Inguruwa, Harangala and Kataboola, who did not show much concern on the quality of green leaves and no attempts were made to attract more producers to increase the quantity. Intensive management was considered as a moderate and a minor problem by $48 \%$ and $44 \%$ of farmers respectively. After properly established, tea plant requires less attention but need timely management practices.

\section{Interaction between extension services and tea smallholder farmers}

Results of interaction between extension service of TRI and TSHDA and tea smallholders showed that the farmers have strong relationship with these Institutions. Accordingly, 58\% mentioned that they think interaction with the extension services will help in attraction of more farmers for tea cultivation, but $6 \%$ of them did not think that extension services would develop interest in farmers. Compared to seminars and workshops, field experiments were more known by farmers. The farmers meeting was the most popular with moderate interaction, while study tours were rarely known by farmers as an tool of extension. On the other hand, seminars, workshops, and field experiments were considered equally useful. Considering study tours as the least important by the farmers may be due to the lack of awareness and experience of it as a tool of extension service.

When questioned on extension services conducted for promoting homegardens, village farmers were found to have limited access. Therefore, it may have effects on sustainable development and maintenance of homegardens compared to tea cultivation.

\section{New techniques and technologies in tea cultivation}

In Sri Lanka, many small-scale technologies have been developed. For example, plucking shear is more frequently used in many plantations. On the other hand, motorized harvesters are available in other countries, but a very limited amount is imported to Sri Lanka mainly due to the high cost and it's non-selective nature of harvesting, having detrimental effects on quality and bush health (Wijerathne, 2012; Piyathissa, et al., 2015). In addition, some large holdings use motorized sprayers for application of weedicides and pesticides. Plucking baskets and fertilizer applicators have also been introduced (Yogaratnam, 2012). New, improved planting material also is available at a reasonable cost, and advisory services are provided free of charge.

Amongst the respondents 58\% were not aware about any new technologies available in tea cultivation. Chi square association test revealed that there was no association $\left(\chi^{2}=51.44\right.$, $\mathrm{P}=0.127$ ) between the age categories and awareness. However, irrespective of this, $84 \%$ of the farmers believed that adoption of new technologies is useful in tea cultivation while $11 \%$ did not have any idea about usefulness of new technologies. Chi square association test revealed that there was no association $\left(\chi^{2}=2.78, \mathrm{P}=0.249\right)$ between the awareness level and knowledge regarding usefulness of new technologies in smallholder tea cultivation.

Some factors which restrict smallholder farmers from adopting new techniques and technologies were identified. High cost of new technologies makes them to stick to traditional farming, with the use of more family labour for their cultivation. Interestingly, $92 \%$ of farmers thought that non-availability of materials was one of the biggest constraints. There was no association $\left(\chi^{2}=3.21, \mathrm{P}=0.361\right)$ between the awareness and availability of new 
technologies (materials) in smallholder tea cultivation. These results are further explained by RSI values presented in figure 2 .

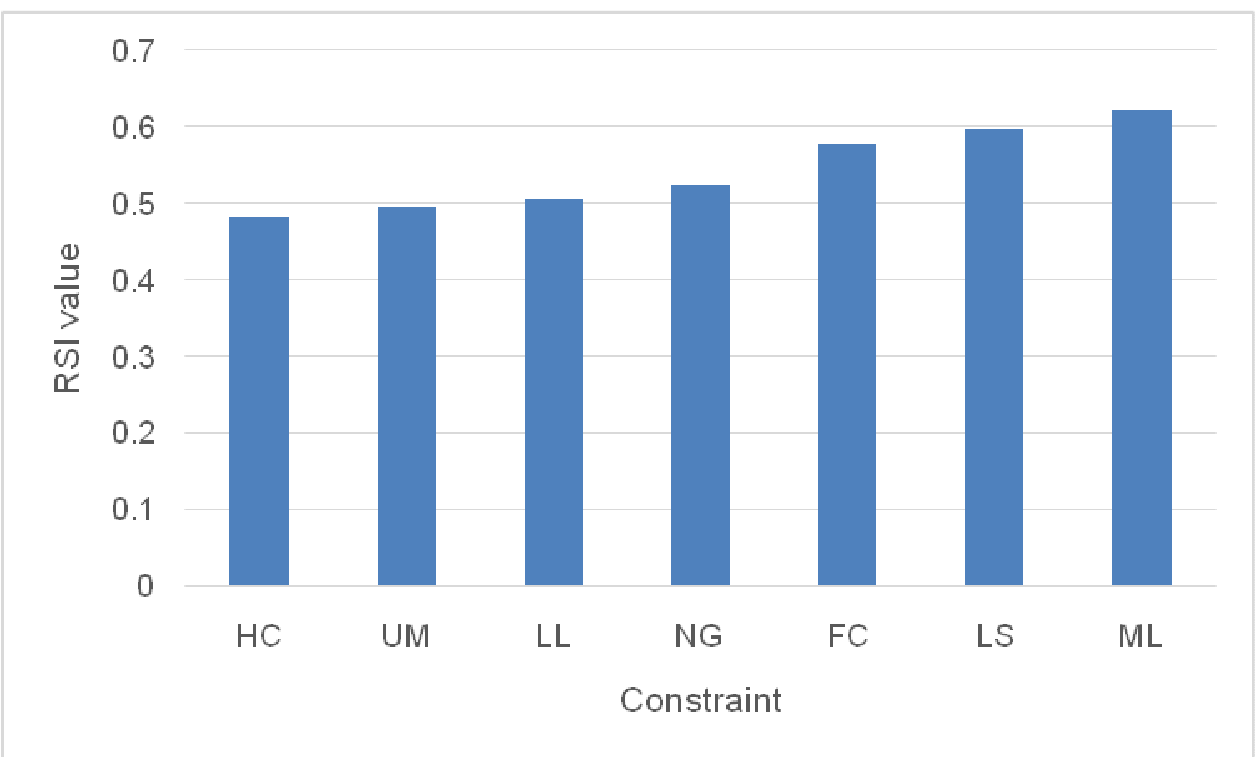

Fig 2. Relative Severity Index (RSI) values of constraints faced when adopting new techniques and technologies in tea cultivation (HC: high cost, UM: material unavailability, LL: limited land, NG: no guidance, FC: poor factory cooperation, LS: lack of staff, ML: require more labour).

\section{Cultivation continuation, expansion and requirement}

About 98\% farmers had a keen interest in continuing tea cultivation in future, and 44\% wanted to expand tea cultivation. Majority of farmers wanted expansion of tea cultivation was because it considered as a source of stable income $(80 \%)$ and had adequate land. Majority of farmers who had no interest in expansion of tea cultivation believed that price/ income was uncertain and had no available land. In addition, about $62 \%$ of farmers believed that tea cultivation may reduce soil fertility and enhance soil erosion in future. For expansion or continuation, most farmers expected availability of land, facilities for land preparation, quality planting materials and new technologies.

In summary, the smallholder tea growers in Aluthgama, Nawalapitiya area put more emphasis on their tea lands, while somewhat neglecting the homegardens, despite several issues and constraints. However, increased transport cost, labour shortage, high wage rates and poor factory conditions lead to increased cost of production, making the sector unsustainable and with greatly reduced profit margins (Thushara, 2015). Uncertainties in the exchange rates, conflicts and break up of economies in importing countries, climate change and natural disasters, etc also cause uncertainties of the tea sector (Yogaratnam 2009; Sirimanna, 2012; Yogaratnam 2012).

A significant majority of homegardens in Sri Lanka (100\% of farmers in studied area) are maintained to produce food (vegetables) for home consumption and the sale of the excess, if any, is being used to derive an income (Sangakkara and Frossard, 2016). This is especially true with respect to the homegardens in the wet zone, which are maintained with a smaller 
contribution to the monthly income because of the smaller extents but tea gives higher income. In addition, in a greater proportion of the homegardens in the country including the homegardens in the wet zone, the productivity was found to be low due to the lack of time dedicated to the management of the units and inadequate maintenance (Sangakkara and Frossard, 2016).

\section{CONCLUSIONS}

Most of the farmers in the Aluthgama, Nawalapitiya area cultivate tea under a mixed cropping system representing adaptation of tea for homegarden systems. Tea cultivation is becoming a challenge for smallholder farmers day by day owing to various issues. Increased cost of production due to fertilizers, labour cost, labour shortage and land problem, despite the involvement of family members towards tea cultivation is significant. In order to overcome uncertain future of tea due to the effect of changing climate and yield declining, promotion and development of tea-based homegarden can be a strong foundation and sustainable method to secure the food and income amongst smallholder farmers in the country by application of proper extension service and introduction of sustainable techniques as a greater investment for future smallholder farmers to secure both food and economic status of family. In this respect, studies should be conducted to evaluate the possibility of promoting homegardening with other cash crops such as tea as future investments to the country to improve rural livelihoods.

\section{Acknowledgement}

The authors wish to offer deepest gratitude for late Prof. Dr. U.R. Sangakkara for the contributions towards the project. The work in this research was supported by a grant from the Nestle Foundation for the study of problems of nutrition in the world, Lausanne, Switzerland, which is gratefully acknowledged. Authors also wish to thank the statistical advices given by Mr. P. Sivashankar of Department of Agribusiness Management, Sabaragamuwa University of Sri Lanka.

\section{REFERENCES}

Cyril, M. B. (2009). Tea Smallholdings Sector in Sri Lanka. Tea Small Holdings Development Authority. ppt: [Accessed on 02.03.2015] Available at www.fao.org/fileadmin/templates/.../IGGtea21/Presentation-SmallholdersSriLanka.ppt.

Darshika, D.W.T.T. and Premalal, K.H.M.S. (2015). Simulate Heavy Rainfall During 19th to 28th December 2014 Using WRF for Different Atmospheric Physics. Sri Lanka Journal of Meteorology, Department of Meteorology. 1(1): 32-40

EDB (2016). Industry Capability Report. Sri Lanka Export Development Board pp:1-10

Fernandes, E.C.M. and Nair, P.K.R. (1986). An evaluation of the structure and function of tropical homegardens. Agricultural Systems 21:279-310 
Fernando, C.J.I.T. (2015). Tea Smallholdings Sector in Sri Lanka. Tea Small Holdings Development Authority. ppt: [Accessed on 02.03.2015] Available at www.mpid.gov.lk/en/images/.../Tea\%20Smallholding\%20Sector\%202015.7.20.pdf

Galhena, D.H., Freed, R. and Maredia, K.M. (2013). Homegardens: a promising approach to enhance household food security and wellbeing. Agriculture \& Food Security 2:8

Hilal, M.I.M. and Mubarak, K.M. (2013). International tea marketing and need for reviving Sri Lankan tea industry. Journal of Management 9(1): 25-38 jm.sljol.info/articles/10.4038/jm.v9i1.7563/galley/5796/download/

http://bizenglish.adaderana.lk/tea-industry-crisis/ [Accessed on 05.06.2016]

http://www.dailymirror.lk/56785/global-big-players-collaborate-to-save-tea-industry

[Accessed on 02.05.2016]

Iyer, K.C. and Jha, K.N. (2006). Critical factors affecting schedule performance: Evidence from Indian construction projects: Journal of construction Engineering and management, ASCE, 132 (8):871-881

Jacob, V.J. and Alles, W.S. (1987). The Kandyan gardens of Sri Lanka. Agroforestry Systems. 5:123-137.

Kottawa-Arachchi, J.D., Gunasekare, M.T.K., Ranatunga, M.A.B., Punyasiri, P.A.N. and Jayasinghe, L. (2013). Use of biochemical compounds in tea germplasm characterization and its implications in tea breeding in Sri Lanka. Journal of the National Science Foundation of Sri Lanka. 41(4):309-318. DOI: http://doi.org/10.4038/jnsfsr.v41i4.6252

Kumar, B.M. and Nair, P.K.R. (2004). The enigma of tropical homegardens. Agroforestry Systems. 61:135-152.

Kumar, B.M. and Nair, P.K.R. (2007). Tropical Homegardens: A Time-tested Example of Sustainable Agroforestry. Pp 1-13. In: Kumar, B.M. and Nair, P.K.R. (Ed.). Tropical Homegardens: A Time-tested Example of Sustainable Agroforestry. Springer Science, Dordrecht.

Landon-Lane, C. (2004). Diversifying rural incomes through homegardens: Livelihood grow in gardens. FAO Diversification booklet 2, Agricultural support systems Division, Food and Agriculture Organization of the United Nations, Rome www.fao.org/3/a-i2463e.pdf

Marsh, R. (1998). Building on traditional gardening to improve household food security. Food Nutr Agr., 22: 4-14

Mohamed, M.T.Z., and Zoysa, A.K.N. (2006). Current status and future research focus of tea in Sri Lanka, The Journal of Agricultural Sciences, 2(2):32-42

Nair, P.K.R. (1993). An Introduction to Agroforestry. Kluwer Academic Publishers, Dordrecht, Netherlands.

http://newsfirst.lk/english/2015/10/nbro-extends-landslide-warnings-to-badulla-ne-kandykegalle-and-other-areas/114616. [Accessed on 01.08.2016] 
Perera. P. (2014). Tea Smallholders in Sri Lanka: Issues and Challenges in Remote Areas, International Journal of Business and Social Science 5(12):107-117

Piyathissa, S.D.S., Kahandage, P.D., Dissanayake, P.K.A.T. and Rambanda, M. (2015). Selective Tea Plucking Machine to Reduce the Labor Involvement. In: Proceedings of International Research Symposium of Rajarata University of Sri Lanka IRSyRUS1 -2015 pp.142-149

Pushpakumara, D.K.N.G., Marambe, B., Silva, G.L.L.P., Weerahewa, J. and Punyawardena, B.V.R. (2012). A review of research on Homegardens in Sri Lanka: The status, importance and future perspective. Tropical Agriculturist, 160:55-77

Sangakkara, U.R. and Frossard, E., (2016). Characteristics of South Asian rural households and associated homegardens - A case study from Sri Lanka, In Press in Tropical Ecology 57(4)

Shyamalie, H.W. (2012). An economic analysis of Sri Lankan tea industry [Accessed on 22/07/2016] Available at dl.nsf.ac.lk/bitstream/handle/1/19754/TB_21_1_1.pdf.

Sirimanna, B. (2012) Bleak future for SL tea smallholders. Business Times. [Accessed on 02.07.2016]Available at http://www.sundaytimes.lk/120401/BusinessTimes/bt12.html.

Thushara, S.C. (2015). Sri Lankan Tea Industry: Prospects and Challenges. Proceedings of the Second Middle East Conference on Global Business, Economics, Finance and Banking (ME15 Dubai Conference) Paper ID: D5331 www.globalbizresearch.org

TSHDA, (2010). Annual report. Tea Smallholder Development Authority, Sri Lanka

TSHDA, (2011). Annual report. Tea Smallholder Development Authority, Sri Lanka

TSHDA, (2012). Annual report. Tea Smallholder Development Authority, Sri Lanka

Warushamana, G. (2013). Labour shortage hits agriculture and industrial sectors. Sunday Observer online. [Accessed on 22.07.2016] Available at www.sundayobserver.lk/2013/03/10/fin30.asp

Watson, M., (2008a). Climatic requirements and soil. pp:10-15. In: Zoyza, A.K.N. (Ed.) Hand Book of tea. Tea Research Institute of Sri Lanka, Thalawakele, Sri Lanka.

Watson, M., (2008b). Harvesting of tea. pp: 94-104. In: Zoyza, A.K.N. (Ed.) Hand Book of tea. Tea Research Institute of Sri Lanka, Thalawakele, Sri Lanka.

Weerakoon, L. (2011). Present situation of homegardens in Sri Lanka: Responses to Homegarden Column, Sunday Island e-paper. [Accessed on 02.03.2015] Available at www.island.lk/index.php?page_cat=article-details\&page $=$ article-

Wijeratne, M.A., Anandacoomaraswamy, A., Amarathunga, M.K.S.L.D., Ratnasiri, J., Basnayake,B.R.S.B. and Kalra, N. (2007). Assessment of impact of climate change on productivity of tea (Camellia sinensis L.) plantations in Sri Lanka. Journal of the National Science Foundation of Sri Lanka. 35(2):119-126. DOI: http://doi.org/10.4038/jnsfsr.v35i2.3676 
Wijeratne, M.A. (2012). Pros \& cons of mechanical 1 harvesting: A review of experience on tea harvesters tested by the tea research institute of Sri Lanka. Tea Bulletin 21(2): 1-9

Yogaratnam, N. (2009) Mitigating challenges of an uncertain future for teahttp://www.nation.lk/2009/08/09/busi3.htm Access on 02/06/2016

Yogaratnam, N. (2012) Uncertainty in Sri Lankan tea business continueshttp://www.dailymirror.lk/21673/uncertainty-in-sri-lankan-tea-business-continues Access on 02/06/2016 